\title{
Fiança sem outorga uxória: causa de nulidade, anulabilidade ou ineficácia?
}

\author{
Nadir Silveira Dias* \\ "Interpretar é, ainda que inconscientemente, tomar partido por uma \\ concepção de direito, o que significa dizer por uma concepção de vida. \\ Interpretar é dar vida a uma norma. (...) O raciocinio e a intuição, todavia, \\ pertencem ao homem, e, por isso, estão prenhes de subjetivismo. \\ Todo intérprete é, embora não o queira, um filósofo e um político da Lei." \\ Eduardo Couture
}

\section{INTRODUÇÃO}

Conquanto nem sempre gostemos, a vida é ditada por definições. Assim na natureza física, na natureza biológica, no micro e no macrocosmos e também na natureza humana. Assim na vida social, na vida individual, no particular ou no universal.

De igual forma, forçosamente, no mundo jurídico, espelho e simultaneamente retrato, registro, de uma sociedade qualquer, estrita ou abrangentemente considerada, num tempo qualquer.

Com este pequeno intróito, outra não é a intenção senão lembrar que o mundo jurídico está repleto de microssistemas que se interligam ou antagonizam na medida dos embates travados no campo das idéias, em prol do bem privado em disputa ou, pior, em detrimento do bem comum.
E por isso mesmo, o objetivo deste trabalho ao tratar do contrato de fiança sem outorga uxória no precípuo fim de responder se tal constitui causa de nulidade, anulabilidade ou de ineficácia.

É de lembrar-se, por oportuno, que não tem ele a pretensão de dizer coisas novas, pois a humanidade conta com cerca de dez mil anos e, por conseguinte, também com quase igual tempo de mundo jurídico (na ínsita concepção do direito que todo ser humano possui), mas tão-só alinhar considerações sobre o tema.

Não poderia dispensar e tampouco fugir na sua apreciação das forçosas definições, pelas quais guia-se o seu desenvolvimento e a idéia do autor.

Não é instigante nem meramente registral, mas de qualquer forma,

* Advogado; pós-graduado; assessor de Desembargador no Tribunal de Justiça do Rio Grande do Sul. 
importante e necessário para o objetivo pós-acadêmico que cuida de apreciar a questão posta, vista no estreito campo que comporta o microssistema do Direito Imobiliário, âmbito de Especialização da Pós-Graduação, mas sem que tal instituto (a fiança) deixe de pertencer, igualmente, a outros campos do Direito e sem que deixe de servir, de igual forma, como aplicativo na prática relacional entre as pessoas e, por conseqüência, na evidenciação dos efeitos que gera na solução de conflitos, geralmente levados e solvidos pelo Judiciário.

Portanto, a análise de Fiança sem Outorga Uxória, Causa de Nulidade, Anulabilidade ou Ineficácia?, conquanto dirigida ao Direito Imobiliário, com tônica particular para aplicação na locação de imóveis urbanos (sua maior abrangência), repito, não descaracteriza o aproveitamento e as aplicações em outros segmentos do instituto.

\section{FIANÇA}

Fiança é contrato acessório, nãocomutativo, e por conseguinte, não oneroso para o afiançado, recebedor da benesse e, como regra, sempre dependente do principal.
No dizer comum, trata-se de confiança, e nesse passo fiança é a responsabilidade assumida por terceiro para solver a obrigação principal assumida pelo afiançado perante o credor, caso aquele não a cumpra.

Segundo Antonio Houaiss, ${ }^{1}$ trata-se de obrigação assumida por terceiro que se responsabiliza pelo devedor enquanto este não puder realizar o seu cumprimento (em sua segunda acepção jurídica). Em referindo-se à pessoa do autor da fiança, o fiador, diz tratar-se do abonador, pessoa que afiança ou assegura o cumprimento dos deveres e obrigações de outro contratante. ${ }^{2}$

Em iguais termos, a definição trazida pela Grande Enciclopédia Larousse Cultural. ${ }^{3}$

Trata-se do ato de abonar obrigação alheia, responsabilidade, garantia, obrigação acessória assumida por terceira pessoa, que se responsabiliza, total ou parcialmente, pelo cumprimento da obrigação do devedor, caso este não venha a cumprila, é abonação, fiadoria, fiador, na sua acepção jurídica, nas palavras de Aurélio Buarque de Holanda Ferreira. ${ }^{4}$

Menos ortodoxo no rigorismo técnico, neste tão-só aspecto, e com um

1 In Pequeno Dicionário Enciclopédico Koogan Larousse, Editora Larousse do Brasil, 1982, p.372: "Obrigação assumida por terceiro que se responsabiliza pelo devedor enquanto esse não puder cumpri-la."

2 In op.cit. p.372: "Abonador, pessoa que afiança ou assegura o cumprimento de deveres e obrigações de outro."

3 In Grande Enciclopédia Larousse Cultural, Ed. Nova Cultural, 1999, v.10, p.2410.

4 In Dicionário Aurélio Básico da Língua Portuguesa, Ed. Nova Fronteira, 1995, p.295: fiança. S.f. 1. Ato (...) de abonar obrigação alheia. 3. Responsabilidade, garantia, 4. Jur. Obrigação acessória assumida por terceira pessoa, que se responsabiliza, total ou 
texto que abrange o dizer comum do povo, Iêdo Batista Neves 5 incorpora à sua definição outros institutos de direito, como caução e penhor, que fiança não são, senão para o colóquio descompromissado, desvinculado do campo do direito.

Nesse ponto, evidentemente, cuidase aqui da Fiança Civil, ${ }^{6}$ em contraponto à Fiança Comercial ou Fiança Mercantil, ${ }^{7}$ ainda que, como afirmado na parte introdutória, possa a análise aqui perseguida servir a outros campos do direito, como este, ora referido.

Ainda em oposição à Fiança Civil da qual aqui se cuida, é de lembrar-se a Fiança Legal, ${ }^{8}$ aquela que deriva de preceito contido em diploma legislativo ou regulamentar, se aquele a tiver previsto, $\mathrm{e}$ também a Fiança Judicial, ${ }^{9}$ esta oriunda de comando judicial, e a partir dos autos de processo sujeito à competência daquele juízo que a determina.

À toda evidência, conclui-se que é a Fiança Convencional ${ }^{10}$ que constitui o objeto estrito deste estudo, agregada a seus outros elementos, e que outra não é senão aquela que forma a maioria de sua incidência, a Fiança Civil Convencional prestada na locação de imóveis urbanos, sem prejuízo de outras congêneres ou não, desde que não excluídas por este estudo ou por sua própria natureza.

Neste caso, e de regra em todos os demais, por certo e cabalmente exigível, precisa ela ser idônea, razão pela qual também é importante lembrar que Fiança Idônea, ${ }^{11}$ ainda segundo Iêdo Batista Neves, é fiança qualificada pela exigência feita ao fiador, além da

parcialmente, pelo cumprimento da obrigação do devedor, caso este não a cumpra ou não possa cumpri-la; abonação, fiadoria, fiador. (...)

5 In Vocabulário Prático de Tecnologia Jurídica e Brocardos Latinos, APM Editora, 1987: "Fiança, s.f. - Diz-se da caução, do penhor, da garantia, da segurança dada por alguém ao cumprimento da obrigação de outro. Diz-se, também, da obrigação acessória, que alguém assume, de satisfazer, perante o credor, a obrigação de terceiro, no caso de este não a cumprir no prazo e nas condições estabelecidas."

6 In op.cit. "II - Fiança Civil - Diz-se da que garante uma obrigação de natureza civil, e compreende todos os acessórios da dívida principal, inclusive despesas judiciais."

7 In op.cit. "III - Fiança Comercial (X - Fiança Mercantil - o mesmo que Fiança Comercial) - Diz-se da que garante uma obrigação comercial e seus acessórios."

8 In op. cit. "IX - Fiança Legal - Diz-se daquela que decorre de exigência de lei."

9 In op.cit. "VIII - Fiança Judicial - Diz-se da que é determinada pelo juiz, de ofício ou a requerimento da parte, para garantia do cumprimento de obrigação de parte no processo."

10 In op.cit. "IV - Fiança Convencional - Diz-se daquela que resulta de contrato, e mediante a qual alguém se obriga a realizar a prestação do devedor principal, se este não a cumprir."

11 In op.cit. "VII - Fiança Idônea - Diz-se daquela que se exige, ao lado da capacidade de obrigar-se do fiador, que ele tenha bens livres e desembaraçados, suficientes para a garantia oferecida." 
capacidade de obrigar-se, também a propriedade de bens livres e desembaraçados, suficientes para a garantia assumida, além da comprovação de capacidade financeira, regra típica e pressuposto primeiro para a garantia de imóveis urbanos.

No magistério do Mestre Orlando Gomes, ${ }^{12}$ o contrato de fiança se dá entre o fiador e o credor da pessoa que recebe a benesse de natureza subsidiária pela razão de a execução restar condicionada ao não cumprimento do contrato principal, esclarecendo que a obrigação fidejussória somente se torna exigível se não cumprida a obrigação principal. Afirma tratar-se de contrato unilateral, gratuito e acessório, produzindo efeitos unicamente para o fiador. ${ }^{13}$

Nesse mesmo sentido o ensinamento de Sylvio Capanema de Souza, Advogado do Mercado Imobiliário,
Professor de Direito Civil da Faculdade Cândido Mendes, e atual Desembargador do Tribunal de Justiça do Rio de Janeiro, ao afirmar constituir-se a fiança em pacto acessório pelo qual alguém, denominado fiador, se obriga perante o credor a pagar a dívida do devedor afiançado, se este não o fizer, ao destacar a preferência do credor por essa modalidade de garantia em sua mais recente obra sobre imóvel urbano. ${ }^{14}$

Para o catedrático de Direito Civil da Faculdade de Direito da Universidade de São Paulo e doutor honoris causa da Faculdade de Direito da Universidade de Paris XII, o também festejado Silvio Rodrigues, leciona que a fiança convencional tem por natureza jurídica ser contrato acessório, unilateral, solene e, não raro, gratuito, chamando a atenção no que respeita a sua interpretação. ${ }^{15}$

12 In Contratos, 10.ed., Forense, Rio de Janeiro, 1984, n.368, p.492: “O contrato de fiança trava-se entre o fiador e o credor do afiançado. Sua natureza é a de um contrato subsidiário, por ter a execução condicionada à inexecução do contrato principal. Por outras palavras, a obrigação fidejussória só se torna exigível se a obrigação principal não for cumprida." 13 In op.cit., n.369, p.493: "Fiança é contrato unilateral, gratuito e acessório. Produz obrigações unicamente para o fiador."

14 In "Da Locação de Imóvel Urbano - Direito e Processo", 1.ed., 2a.tiragem, Forense, Rio de Janeiro, 1999, n.165. p.240-241: "De todas as garantias admitidas pela lei, a mais utilizada é a fiança, que constitui pacto acessório pelo qual alguém, a quem chamamos de fiador, se obriga, perante o credor, a pagar a dívida do devedor, afiançado, caso este não o faça. (...). Trata-se de contrato acessório, sendo de sua própria natureza a gratuidade, embora se admita que tal se transforme em oneroso, quando se convenciona remuneração do fiador, tal como ocorre na fiança comercial ou bancária."

15 In Direito Civil, dos Contratos e das Declarações Unilaterais da Vontade, Vol. 3, Editora Saraiva, 22.ed., 1994, n.179, p.370-371: "Natureza jurídica-A fiança convencional, objeto deste Capítulo, é contrato acessório, unilateral, solene e, no geral, gratuito. (...) O fato da fiança ser contrato gratuito implica a incidência da regra do art. 1.090 do Código Civil, que ordena sejam as convenções benéficas interpretadas estritamente. Isto é, não se pode, por analogia, ampliar as obrigações do fiador, quer no respeitante à sua abrangência, quer no concernente à sua duração (...)." 
Para o autor, ${ }^{16}$ a seu turno, sem prejuízo de outras aplicações, e em estudo já publicado sobre a legislação inquilinária, Fiança (Civil Convencional) é o instituto de direito civil trazido para o âmbito da legislação especial esparsa que disciplina a locação de imóveis urbanos e é a modalidade de garantia prevista no inciso II do artigo 37 da Lei Inquilinária, enquanto na lei comum codificada, encontra-se disciplinada nos artigos 1481 a 1504 do Código Civil.

$\mathrm{E}$, contrariamente ao que ocorre com a caução, é a preferida por locadores ou por seus representantes, as administradoras de imóveis, na medida em que calcada em comprovação de renda por parte do fiador e na comprovação de uma ou duas propriedades livres e desembaraçadas de quaisquer ônus, legais ou convencionais, o que garante, sobremaneira, o valor da locação.

Corresponde a afirmar que não basta ao fiador ter a vontade de afiançar uma pessoa para ser ele locatário (coisa que raramente alguém quer ser), mas cujo objetivo é evidenciar que, além disso, visto que ausente não pode estar o seu consentimento, precisa o fiador comprovar situação econômico-financeira para demonstrar a capacidade de pagamento, caso o locatário não o faça.

Assim fazendo, por certo que terá a aprovação de seu cadastro e a aceitação do locador, quando então poderá firmar o contrato de locação, em geral reconhecido por autenticidade, e tão-só raramente por semelhança, pelo tabelião ou ajudante juramentado, no tabelionato de notas, atual denominação dos antigos Cartórios de Notas. A transcrição dos artigos lá objetivou o maior entendimento do instituto e a sua melhor ou mais adequada aplicação, aqui levada para o item 7 .

\section{OUTORGA UXÓRIA}

Outorga uxória é consentimento, o assentimento de vontade, a manifestação de anuência, por parte daquele que deve participar do ato de concessão da fiança convencional. É de ser do marido ou da mulher, dependendo de quem seja o autor concedente da garantia consubstanciada no contrato de fiança.

Antonio Houaiss, ${ }^{17}$ define a outorga como o consentimento, enquanto uxório é o que diz respeito à mulher casada.

No mesmo sentido, é o dizer de Aurélio Buarque de Holanda Ferreira. ${ }^{18}$

16 In Locação de Imóveis Comentada em Locuções e Verbetes, Editora Livraria do Advogado, 1999, n.198, p.122-123.

17 In op.cit. p.611: "Outorga: s.f. Ação ou efeito de outorgar; concessão; beneplácito; consentimento." p. 863: "Uxório: adj. Que diz respeito à mulher casada."

18 In op.cit. p.472: "Outorga. S. f. Ato ou efeito de outorgar; consentimento; concessão; aprovação; beneplácito." p.661: "Uxório (cs). Adj. Respeitante à mulher casada." 
Não discrepa dessa definição Iêdo Batista Neves, bipartindo-a em outorga marital e outorga uxória. ${ }^{19}$

Para Sylvio Capanema, ${ }^{20}$ a outorga uxória ou marital é condição de validade e eficácia da fiança. Quando concedida por apenas um dos cônjuges, importa ausência da outorga e nulidade da garantia, sem deixar de fazer referência à existência de corrente doutrinária que admite a sua validade com o comprometimento daquele que concedeu a fiança.

O Professor Silvio Rodrigues, por sua vez, afirma que a outorga uxória é o consentimento da mulher, enquanto sustenta que na fiança prestada sem ela não se cuidará de nulidade absoluta, na medida em que suscetível de conva- lidação mediante ratificação que pode fazer a mulher, ${ }^{21} \mathrm{e}$, também o marido, se for o caso de outorga marital.

\section{NULIDADE}

No que respeita à nulidade, a definição trazida pelo reconhecido dicionarista Antonio Houaiss nos diz que ela é um estado do ato jurídico que se encontra gravado de vício, que o impede de existir legalmente e de produzir os seus efeitos. Diz ainda que a nulidade absoluta pode ser invocada por qualquer pessoa interessada, a nulidade relativa somente pelas pessoas a quem aproveita. ${ }^{22}$

A seu turno, não menos reconhecido, o festejado dicionarista Aurélio Buarque de Holanda Ferreira afirma

19 In op.cit.: "Outorga, s.f.- Diz-se do consentimento; da permissão; do mandato." I Outorga Marital - Diz-se do consentimento do marido para que a mulher pratique certos atos segundo a lei. II - Outorga Uxória - Diz-se do consentimento da mulher casada, necessário para que o marido pratique determinados atos, especialmente no que toca à alienação de bens móveis." N.A. (aqui, certamente, houve erro de digitação, pois a referência é de ser a bens imóveis).

20 In op.cit., n.166, p.242: “A outorga é condição de validade e eficácia da fiança, pelo que a sua ausência importará, inexoravelmente, em nulidade da garantia, em que pese uma corrente doutrinária sustentar que será válida, com o comprometimento apenas da meação do consorte que a concedeu."

21 In op.cit. n.179-A, p.371: “A fiança e a outorga uxória - Tratando-se de negócio em geral gratuito, no qual o fiador arrisca seus bens, pois, se o devedor principal não pagar a dívida, o fiador deve fazê-lo, impede o legislador que o homem casado preste fiança, sem o consentimento de sua mulher (CC, art. 235, III). As razões inspiradoras da lei já foram sucintamente analisadas (v. n. 63, III, v. 6), tendo-se sustentado que a nulidade da fiança, prestada sem outorga uxória, não é absoluta, por ser suscetível de convalescimento, através de ratificação da mulher (...)."

22 In op.cit., p.592: "NULIDADE, s.f. Qualidade do que é nulo./(...) Falta de validade./ Estado de um ato jurídico gravado de vício, que o impede de existir legalmente e de produzir efeitos. (A nulidade absoluta pode ser invocada por qualquer pessoa interessada, a nulidade relativa só pelas pessoas a quem deve proteger." 
em sua definição que a nulidade é o estado ou qualidade de nulo, apontando para a acepção jurídica que diz ser a ineficácia de um ato jurídico, pela ausência de condições necessárias à sua validade. ${ }^{23}$

Para Iêdo Batista Neves, no direito judiciário, nulidade é o vício causado por erro ou carência de formas essenciais do ato, que o tornam inválido ou inoperante em relação ao direito processual. Suas múltiplas e variadas definições são de todo significativas para esse trabalho e razão bastante para a citação, in totum. ${ }^{24}$

23 In op.cit., p.458-459: "nulidade. S.f. 1. Estado ou qualidade de nulo. (...) 4. Jur. Ineficácia dum ato jurídico, resultante da ausência de uma das condições necessárias para sua validade." 24 In op. cit. "NULIDADE, s. f. - Diz-se da qualidade do que é nulo; da ineficácia total ou parcial do ato jurídico a que falta alguma formalidade ou solenidade intrínseca ou extrínseca que lhe é essencial. Em direito judiciário, diz-se do vício, por erro ou preterição de formas essenciais, que torna inválida, ou inoperante, uma relação de direito processual.

I - Nulidade Absoluta - Diz-se da nulidade insanável.

II - Nulidade Acidental - Diz-se da nulidade relativa.

III - Nulidade Dependente de Rescisão - O mesmo que Nulidade Relativa ou Ato Anulável. IV - Nulidade Essencial - Diz-se da nulidade de fundo. Diz-se, também, da nulidade formal, quando a lei impõe determinada forma ao ato.

$\mathrm{V}$ - Nulidade Expressa - Diz-se da que está prevista na letra da lei.

VI - Nulidade Extrínseca - Diz-se da nulidade absoluta que decorre da omissão de forma que a lei considera substancial ao ato.

VII - Nulidade Formal - Diz-se daquela que atinge o ato que não obedeceu ao modo prescrito em lei.

VIII - Nulidade Imperativa - Diz-se da que decorre da substância do ato.

IX - Nulidade Insuprível - Diz-se da nulidade insanável; do ato que não pode ser ratificado nem pode produzir efeitos.

$X$ - Nulidade Intrínseca - Diz-se da que decorre de vício interior do ato.

XI - Nulidade Legal - Diz-se da que é proclamada por lei.

XII - Nulidade Parcial - Diz-se daquela que não prejudicará o ato na parte válida, se esta for separável.

XIII - Nulidade Material - Diz-se da nulidade de direito substantivo; da que atinge o conteúdo do ato.

XIV - Nulidade Relativa - Diz-se da que resulta da incapacidade relativa do agente ou de vício de vontade, e não pode ser alegada pela parte prejudicada e declarada existente por meio de ação própria. V. Nulidade Acidental.

XV - Nulidade Substancial - Diz-se da que consiste no estado dum ato em que há vícios intrínsecos ou extrínsecos insupríveis, que impedem tenha ele existência legal e que produza seus efeitos jurídicos circunstância que pode ser alegada por qualquer interessado ou pelo Ministério Público, cumprindo ao juiz decretar de ofício a invalidade completa desse ato desde que o conheça. V. Nulidade Absoluta.

XVI - Nulidade Tácita - V. Nulidade Virtual.

XVII - Nulidade Taxativa - Diz-se da nulidade expressa como cominação para a falta de cumprimento das formalidades que a lei considera essenciais para a existência válida do ato. É a que só se refere a casos determinados. 
Segundo Cario Mário da Silva Pereira, professor emérito da Universidade Federal do Rio de Janeiro e da Universidade de Minas Gerais, nulidade é a sanção para a ofensa ao que predeterminou a lei, ainda que nem sempre esteja ela prevista ou declarada na própria lei, às vezes tão-só enunciando o princípio e cominando a penalidade ${ }^{25}$.

No magistério de Maria Helena Diniz, titular de Direito Civil e professora de Filosofia do Direito em PósGraduação em Direito da PUCRS, nulidade é a sanção imposta pela norma legal com a determinação de privação dos efeitos do negócio jurídico praticado sem a sua observância. ${ }^{26}$

\section{ANULABILIDADE}

Anulabilidade, por sua vez, na definição de Antonio Houaiss é a qualificação do que é anulável, enquanto anulação é a ação de anular e, anular, o que pode ser declarado nulo, sem efeito, para anular o negócio, e anulável, o que pode ser anulado, revogável. ${ }^{27}$

Para Aurélio Buarque de Holanda Ferreira, anular está definido como tornar nulo, invalidar, anulatório, o que tem força de anular, a capacidade de anular, e anulável é o que pode ou deve ser anulado. ${ }^{28}$

Iêdo Batista Neves, em suas definições, aponta-nos que a anulabilidade é a característica do anulável, por defeito

XVIII - Nulidade Textual - Diz-se daquelas expressamente previstas no texto da lei.

XIX - Nulidade Virtual - Diz-se da que decorre do espírito da lei. O mesmo que Nulidade Tácita. XX - Nulidade Visceral - Diz-se da falta de um elemento substancial para a existência do ato. V. Nulidade Substancial.

XXI - Nulidade de Sentença - Diz-se da que ocorre no julgamento em que são preteridas prescrições legais que não poderiam deixar de ser observadas."

25 In Instituições de Direito Civil, Vol. I, Introdução do Direito Civil, Teoria Geral de Direito Civil, 9.ed., Forense, Rio de Janeiro, 1986, n.109, p.439-441: "É nulo o negócio jurídico, quando, em razão do defeito grave que o atinge, não pode produzir o almejado efeito. É a nulidade a sanção para a ofensa à predeterminação legal. Nem sempre, contudo, se acha declarada na própria lei. Às vezes, esta enuncia o princípio, imperativo ou proibitivo, cominando a pena específica ao transgressor, e, então, diz-se que a nulidade é expressa ou textual; outras vezes, a lei proíbe o ato ou estipula a sua validade na dependência de certos requisitos, e, se é ofendida, existe igualmente nulidade, que se dirá implícita ou virtual. (...)" 26 In Curso de Direito Civil Brasileiro, $1^{\circ}$ Vol., Teoria Geral do Direito Civil, 4.ed., Editora Saraiva, 1986, H. h.1., p.258: "A nulidade vem a ser a sanção, imposta pela norma jurídica, que determina a privação dos efeitos jurídicos do negócio jurídico praticado em desobediência ao que prescreve (163. Orlando Gomes...; Caio M. S. Pereira...)."

27 In op.cit., p.58: "Anulabilidade, s.f. Qualidade de anulável. Anulação, s.f. Ação de anular; abolição, revogação: a anulação de um casamento. Anular², v.t. Tornar, declarar nulo, sem efeito: anular o negócio. Anulável, adj. Que pode ser anulado; revogável."

28 In op.cit., p.49: "anular². V.t. 1. Tornar nulo; invalidar. 2. Reduzir a nada; destruir, eliminar, aniquilar. 3. Destruir o efeito de; resistir a. (...). anulatório. Adj. Jur. Que tem força de anular; capaz de anular. anulável. Adj. 2 g. Que se pode ou deve anular." 
que pode ser sanado pela parte; anulação, a rescisão do ato ou negócio jurídico; anular, o desfazimento do ato ou do negócio jurídico, acrescendo que anular significa existência, ainda que com defeito; anulatório, o que tem força ou aptidão para anular e anulável, o que pode ser desfeito ou rescindido. ${ }^{29}$

Discorrendo sobre a anulabilidade, Caio Mário da Silva Pereira leciona que ela não tem o mesmo alcance da nulidade, pois ausente o interesse público, mas a mera conveniência das partes, aduzindo ainda que em doutrina visa ela proteger o consentimento, podendo ainda referir-se à incapacidade do autor da manifestação volitiva. ${ }^{30}$
No magistério de Maria Helena Diniz, a anulabilidade ou nulidade relativa, citando Clóvis Beviláqua, é relativa àqueles negócios que se encontram com vício capaz de determinar a sua ineficácia, e que podem ser eliminados para restaurar-lhes a normalidade, acrescentando que se trata de desconformidade que a norma jurídica considera de menor gravidade, concernente à esfera de interesses individuais. ${ }^{31}$

\section{INEFICÁCIA}

Sobre a ineficácia, Antonio Houaiss esclarece em sua definição que ela é a ausência de eficácia, inutilidade ou

29 In op. cit. “Anulabilidade, s.f. - Diz-se do que é anulável, isto é, do ato ou negocio jurídico defeituoso porque lhe faltam requisitos previstos em lei, mas cujo desfazimento depende de argüição do prejudicado. Pode ser sanado por ato da parte ou das partes interessadas. A anulabilidade é defeito menos grave do que a nulidade. Anulação, s.f. Diz-se da rescisão do ato ou do negócio jurídico. Anular, v.t. - Desfazer o ato ou o negócio jurídico. Não se confunde com decretação de nulidade, que é declarar inexistente o ato jurídico. Anular pressupõe existir, embora com defeito. Anulável, s.f. - Diz-se do que pode ser desfeito ou rescindido: negócio anulável; decisão anulável."

30 In op.cit., n.110, p.442-443: “Anulabilidade. Não tem o mesmo alcance da nulidade, nem traz o mesmo fundamento a anulabilidade do negócio jurídico. Nela não se vislumbra o interesse público, porém a mera conveniência das partes, já que na sua instituição o legislador visa à proteção de interesses privados. ${ }^{12}$ (De Page, Traité, n 98 ) (...) Diz-se em doutrina que a anulabilidade visa à proteção do consentimento ou refere-se à incapacidade do agente. ${ }^{13}$ (Planiol, Ripert et Boulanger, $n^{\circ} 351$.)"

31 In op.cit. H. h.1. "A nulidade relativa ou anulabilidade refere-se "a negócios que se acham inquinados de vício capaz de lhes determinar a ineficácia, mas que poderá ser eliminado, restabelecendo-se a sua normalidade" (165. Esta é a definição de Clóvis Beviláqua (op.cit. p.281). A declaração judicial de sua ineficácia opera ex nunc, de modo que o negócio produz efeitos até esse momento (CC, art. 152). Isto é assim porque a anulabilidade se prende a uma desconformidade que a norma considera menos grave, uma vez que o negócio anulável viola preceito concernente a interesses meramente individuais, acarretando uma reação menos extrema (CC, arts. 147, I e II; 155 a 158) (...)" 
insuficiência que não produz os resultados desejados. ${ }^{32}$

Nas palavras de Aurélio Buarque de Holanda Ferreira, ineficácia é a qualidade de ineficaz, o que não tem eficácia, e ineficaz, o que é não eficaz, inútil, inconveniente. ${ }^{33}$

Sem discrepar dessas definições, Iêdo Batista Neves afirma que a ineficácia trata-se da inutilidade ou insuficiência do ato para produzir efeitos, enquanto que ineficaz se traduz por ausência de qualidade do ato para a produção de efeitos jurídicos. ${ }^{34}$

Caio Mário da Silva Pereira, ao discorrer sobre os efeitos da nulidade e da anulabilidade, por via transversa ou indireta, favorece a idéia aqui desenvolvida ao sustentar que a ineficácia da obrigação acessória da fiança não leva à ineficácia da obrigação principal. ${ }^{35}$

Ainda que expostos na análise da nulidade do negócio jurídico, Maria Helena Diniz afirma nulos os atos negociais com vícios essenciais e sem qualquer eficácia jurídica. ${ }^{36}$

\section{LEGISLAÇÃO}

\subsection{Código Civil Brasileiro}

Art. 1481. Dá-se o contrato de fiança, quando uma pessoa se obriga por outra, para com o seu credor, a satisfazer a obrigação, caso o devedor não a cumpra.

Art. 1482. Se o fiador tiver quem lhe abone a solvência, ao abonador se aplicará o disposto neste capítulo sobre fiança. Art. 1483. A fiança dar-se-á por escrito, e não admite interpretação extensiva. Art. 1484. Pode-se estipular a fiança, ainda sem consentimento do devedor. Art. 1485. As dívidas futuras podem ser objeto de fiança; mas o fiador, neste caso, não será demandado senão depois que se fizer certa e líquida a obrigação do principal devedor.

Art. 1486. Não sendo limitada a fiança, compreenderá todos os acessórios da dívida principal, inclusive as despesas judiciais, desde a citação do fiador. Art. 1487. A fiança pode ser de valor inferior ao da obrigação principal e contraída em condições menos onerosas.

32 In op.cit., p.464: “Ineficácia, s.f. Falta de eficácia; inutilidade, insuficiência que não produz os efeitos desejados."

33 In op.cit., p.359: "ineficácia. S.f. Qualidade de ineficaz; falta de eficácia. Ineficaz. Adj. 2 g. Não eficaz; inútil, inconveniente."

34 In op.cit. "Ineficácia, s. f. - Diz-se da inutilidade da insuficiência do ato para produzir efeitos jurídicos. Ineficaz, adj. - Diz-se da ausência de qualidade do ato para produzir efeito jurídico."

35 In op.cit. n. ${ }^{\circ} 111$, p.444: "Quando uma obrigação é dependente de outra, a nulidade da principal fulmina a acessória, mas a recíproca não é verdadeira, pois a ineficácia da acessória não macula a principal, que continua produzindo os seus efeitos, como seria o caso da obrigação garantida por fiança, em que a nulidade da obrigação principal extingue a garantia, mas se for nula a fiança, subsiste o débito."

36 In op.cit. H, h.1. p.268:”(...) São nulos os atos negociais inquinados por vícios essenciais, não podendo ter, obviamente, qualquer eficácia jurídica. P. ex. (CC, art. 145) (...).” 
Quando exceder o valor da dívida, ou for mais onerosa, que ela, não valerá senão até ao limite da obrigação afiançada. Art. 1488. As obrigações nulas não são suscetíveis de fiança, exceto se a nulidade resultar apenas de incapacidade pessoal do devedor.

Parágrafo único. Esta exceção não abrange o caso do art. 1.259.

Art. 1489. Quando alguém houver de dar fiador, o credor não pode ser obrigado a aceitá-lo se não for pessoa idônea, domiciliada no município, onde tenha de prestar a fiança, e não possua bens suficientes para desempenhar a obrigação. Art. 1490. Se o fiador se tornar insolvente, ou incapaz, poderá o credor exigir que seja substituído.

\section{Efeitos da Fiança}

Art. 1491. O fiador demandado pelo pagamento da dívida tem direito a exigir, até a contestação da lide, que sejam primeiro excutidos os bens do devedor. Parágrafo único. - O fiador, que alegar o benefício de ordem a que se refere este artigo, deve nomear bens do devedor, sitos no mesmo município, livres e desembargados, quantos bastem para solver o débito (art. 1.504). Art. 1492. Não aproveita este benefício ao fiador:

I - Se ele o renunciou expressamente.

II - Se se obrigou como principal pagador, ou devedor solidário.

III - Se o devedor for insolvente, ou falido.

Art. 1493. A fiança conjuntamente prestada a um só débito por mais de uma pessoa, importa o compromisso de solidariedade entre elas, se declaradamente não se reservaram o benefício da divisão.

Parágrafo único. Estipulado este benefício, cada fiador responde unicamente pela parte que, em proporção, lhe couber no pagamento.

Art. 1494. Pode também cada fiador taxar, no contrato, a parte da dívida que toma sob sua responsabilidade, e, neste caso, não será obrigado a mais.

Art. 1495. O fiador, que pagar integralmente a dívida, fica sub-rogado nos direitos do credor; mas só poderá demandar a cada um dos outros fiadores pela respectiva quota.

Parágrafo único. A parte do fiador insolvente distribuir-se-á pelos outros. Art. 1496. O devedor responde também ao fiador por todas as perdas e danos que este pagar, e pelos que sofrer em razão da fiança.

Art. 1497. O fiador tem direito aos juros do desembolso pela taxa estipulada na obrigação principal, e, não havendo taxa convencionada, aos juros legais da mora.

Art. 1498. Quando o credor, sem justa causa, demorar a execução iniciada contra o devedor, poderá o fiador, ou o abonador (art. 1.482), promover-lhe $\mathrm{o}$ andamento.

Art. 1499. O fiador, ainda antes de haver pago, pode exigir que o devedor satisfaça a obrigação, ou o exonere da fiança, desde que a dívida se torne exigível, ou tenha decorrido o prazo dentro no qual o devedor se obrigou a desonerá-lo.

Art. 1500. O fiador poderá exonerar-se da fiança que tiver assinado sem limitação de tempo, sempre que lhe convier, ficando, porém, obrigado por todos os efeitos da fiança, anteriores ao ato amigável, ou à sentença que o exonerar. Art. 1501. A obrigação do fiador passalhe aos herdeiros; mas a responsabilidade da fiança se limita ao tempo decorrido até a morte do fiador, e não pode ultrapassar as forças da herança. 


\section{Extinção da Fiança}

Art. 1502. O fiador pode opor ao credor as exceções que lhe forem pessoais, e as extintivas da obrigação que compitam ao devedor principal, se não provierem simplesmente de incapacidade pessoal, salvo o caso do art. 1.259.

Art. 1503. O fiador, ainda que solidário com o principal devedor (arts. $1.492 \mathrm{e}$ 1.493), ficará desobrigado:

I - Se, sem consentimento seu, o credor conceder moratória ao devedor.

II - Se, por fato do credor, for impossível a sub-rogação nos seus direitos e preferências.

III - Se o credor, em pagamento da dívida, aceitar amigavelmente do devedor objeto diverso do que este era obrigado a lhe dar, ainda que depois venha a perdê-lo por evicção.

Art. 1504. Se, feita a nomeação nas condições do art. 1.491, parágrafo único, o devedor, retardando-se a execução, cair em insolvência, ficará exonerado o fiador, provando que os bens por ele indicados eram, ao tempo da penhora, suficientes para a solução da dívida afiançada."

$145 \mathrm{INC}-\mathrm{V}$

\section{DAS NULIDADES}

“Art. 145. É nulo o ato jurídico:

I - quando praticado por pessoa absolutamente incapaz (artigo $5^{\circ}$ ).

II - quando for ilícito, ou impossível, o seu objeto.

III - quando não revestir a forma prescrita em lei (art. 82 e 130).

IV - quando for preterida alguma solenidade que a lei considere essencial para a sua validade.

$\mathrm{V}$ - quando a lei taxativamente o declarar nulo ou the negar efeito."

146PAR-ÚNICO

"Art. 146. As nulidades do artigo antecedente podem ser alegadas por qualquer interessado, ou pelo Ministério Público, quando lhe couber intervir. Parágrafo único. Devem ser pronunciadas pelo juiz, quando conhecer do ato ou dos seus efeitos e as encontrar provadas, não lhe sendo permitido suprilas, ainda a requerimento das partes."

NB: 1) Ver CCB, art. 222. 2) Ver Lei n. ${ }^{\circ}$ 6.015/73, Lei dos Registros Públicos, art. 214, no mesmo sentido.

“Art. 147. É anulável o ato jurídico:

I - por incapacidade relativa do agente (art. $6^{\circ}$ ).

II - por vício resultante de erro, dolo, coação, simulação, ou fraude (arts. 86 a 113)."

NB: Ver CCB, arts. 83, 154 a 157.

"Art. 148. O ato anulável pode ser ratificado pelas partes, salvo direito de terceiro. A ratificação retroage à data do ato." NB:1) Ver CCB, art. 1.008. 2) Ver Súmulas 335 e 346 do STF

"Art. 149. O ato de ratificação deve conter a substância da obrigação ratificada e a vontade expressa de ratificá-la." NB: A ratificação somente pode ser efetivada por ato da mesma natureza do documento original; se for o caso de escritura pública, a ratificação só terá validade se também for lavrada por instrumento público.

“Art. 150. É escusada a ratificação expressa, quando a obrigação já foi cumprida em parte pelo devedor, ciente do vício que a inquinava."

"Art. 151. A ratificação expressa, ou a execução voluntária da obrigação anulável, nos termos dos arts. 148 a 150, importa renúncia a todas as ações, ou exceções, de que dispusesse contra o ato o devedor."

“Art. 152. As nulidades do art. 147 não têm efeito antes de julgadas por sentença, nem se pronunciam de ofício. Só os interessados as podem alegar, e aproveitam exclusivamente aos que as 
alegarem, salvo o caso de solidariedade, ou indivisibilidade.

Parágrafo único. A nulidade do instrumento não induz a do ato, sempre que este puder provar-se por outro meio." 178 PAR-9 INC-I LET-B

"Art. 178. Prescreve:

$\S 9^{\circ}$. Em quatro anos:

I - Contados da dissolução da sociedade conjugal, a ação da mulher para:

a) desobrigar ou reivindicar os imóveis do casal, quando o marido os gravou, ou alienou sem outorga uxória, ou suprimento dela pelo juiz (art. 235 e 237); b) anular as fianças prestadas e as doações feitas pelo marido fora dos casos legais (arts. 235, $\mathrm{n}^{\circ}$ s. III e IV, e 236);" (Redação do Dec. Legislativo n. ${ }^{\circ}$ $3.725 / 19)$ 235 INC-III

“Art. 235. O marido não pode, sem consentimento da mulher, qualquer que seja o regime de bens:

I - Alienar, hipotecar ou gravar de ônus real os bens imóveis, ou direitos reais sobre imóveis alheios (arts. 178, § $9^{\circ}$, n. ${ }^{\circ}$ I, a, 237 , 276 e 293). (Redação do Dec. Leg. 3.725/19)

II - Pleitear, como autor ou réu, acerca desses bens e direitos.

III - Prestar fiança (arts. $178, \S 9^{\circ}$, n. $^{\circ} \mathrm{I}, \mathrm{b}$ e 263, n. $\left.{ }^{\circ} \mathrm{X}\right) . "$

239

"Art. 239. A anulação dos atos do marido praticados sem outorga da mulher, ou sem suprimento do juiz, só poderá ser demandada por ela, ou seus herdeiros (arts. $178, \S 9^{\circ}$, n. $^{\circ}$ I, a e n..$^{\circ}$ II)."

NB: Ver CCB, arts. 240 e seg.

242

"Art. 242. A mulher não pode, sem autorização do marido (art. 251):

I - Praticar atos que este não poderia sem consentimento da mulher (art. 235). II - Alienar ou gravar de ônus real, os imóveis de seu domínio particular, qualquer que seja o regime dos bens (arts. 263, n's II, III e VIII, 269, 275 e 310). III - Alienar os seus direitos reais sobre imóveis de outrem.

IV - Contrair obrigações que possam importar em alheação de bens do casal." (Redação dos incisos dada pela Lei n. ${ }^{\circ}$ 4.121, de 27.08.62).

7.2. No NOVO CÓDIGO CIVIL BRASILEIRO (Lei $\mathrm{n}^{\circ} \mathbf{1 0 . 4 0 6}$, de 10 de janeiro de 2002)

"LIVRO IV. Do Direito de Família. TítUlo I Do Direito Pessoal. SUBTÍTULO I Do Casamento. TÍTULO II Do Direito Patrimonial. Subtítulo I Do Regime de Bens entre os Cônjuges. CAPÍTULO I

Disposições Gerais"
"Art. 1.642. Qualquer que seja o regime
de bens, tanto o marido quanto a mulher
podem livremente: (...)

III - desobrigar ou reivindicar os imóveis que tenham sido gravados ou alienados sem o seu consentimento ou sem suprimento judicial;

IV - demandar a rescisão dos contratos de fiança e doação, ou a invalidação do aval, realizados pelo outro cônjuge com infração do disposto nos incisos III e IV do art. 1.647;

Art. 1.647. Ressalvado o disposto no art. 1.648, nenhum dos cônjuges pode, sem autorização do outro, exceto no regime da separação absoluta:

I - alienar ou gravar de ônus real os bens imóveis;

II - pleitear, como autor ou réu, acerca desses bens ou direitos; III - prestar fiança ou aval;

(...) 
Art. 1.648. Cabe ao juiz, nos casos do artigo antecedente, suprir a outorga, quando um dos cônjuges a denegue sem motivo justo, ou lhe seja impossível concedê-la.

Art. 1.649. A falta de autorização, não suprida pelo juiz, quando necessária (art. 1.647), tornará anulável o ato praticado, podendo o outro conjuge pleitear-lhe a anulação, até dois anos depois de terminada a sociedade conjugal.

Parágrafo único. A aprovação torna válido o ato, desde que feita por instrumento público, ou particular, autenticado."

"PAR TE ES PEC IAL

LIVRO I. DO DIREITO DAS OBRIGAÇÕES. TÍTULO VI. Das Várias

Espécies de Contrato

\section{CAPÍTULO XVIII. DA FIANÇA}

Seção I Disposições Gerais

Art. 818. Pelo contrato de fiança, uma pessoa garante satisfazer ao credor uma obrigação assumida pelo devedor, caso este não a cumpra.

Art. 819. A fiança dar-se-á por escrito, e não admite interpretação extensiva.

Art. 820. Pode-se estipular a fiança, ainda que sem consentimento do devedor ou contra a sua vontade.

Art. 821. As dívidas futuras podem ser objeto de fiança; mas o fiador, neste caso, não será demandado senão depois que se fizer certa e líquida a obrigação do principal devedor.

Art. 822. Não sendo limitada, a fiança compreenderá todos os acessórios da dívida principal, inclusive as despesas judiciais, desde a citação do fiador.

Art. 823. A fiança pode ser de valor inferior ao da obrigação principal e contraída em condições menos onerosas, e, quando exceder o valor da dívida, ou for mais onerosa que ela, não valerá senão até ao limite da obrigação afiançada.

Art. 824. As obrigações nulas não são suscetíveis de fiança, exceto se a nulidade resultar apenas de incapacidade pessoal do devedor.

Parágrafo único. A exceção estabelecida neste artigo não abrange o caso de mútuo feito a menor.

Art. 825. Quando alguém houver de oferecer fiador, o credor não pode ser obrigado a aceitá-lo se não for pessoa idônea, domiciliada no município onde tenha de prestar a fiança, e não possua bens suficientes para cumprir a obrigação. Art. 826. Se o fiador se tornar insolvente ou incapaz, poderá o credor exigir que seja substituído.

Seção II

\section{Dos Efeitos da Fiança}

Art. 827. O fiador demandado pelo pagamento da dívida tem direito a exigir, até a contestação da lide, que sejam primeiro executados os bens do devedor. Parágrafo único. $\mathrm{O}$ fiador que alegar o benefício de ordem, a que se refere este artigo, deve nomear bens do devedor, sitos no mesmo município, livres e desembargados, quantos bastem para solver o débito.

Art. 828. Não aproveita este benefício ao fiador:

I - se ele o renunciou expressamente;

II - se se obrigou como principal pagador, ou devedor solidário;

III - se o devedor for insolvente, ou falido. Art. 829. A fiança conjuntamente prestada a um só débito por mais de uma pessoa importa o compromisso de solidariedade entre elas, se declaradamente não se reservarem o benefício de divisão.

Parágrafo único. Estipulado este benefício, cada fiador responde unicamente 
pela parte que, em proporção, lhe couber no pagamento.

Art. 830. Cada fiador pode fixar no contrato a parte da dívida que toma sob sua responsabilidade, caso em que não será por mais obrigado.

Art. 831. O fiador que pagar integralmente a dívida fica sub-rogado nos direitos do credor; mas só poderá demandar a cada um dos outros fiadores pela respectiva quota.

Art. 832. O devedor responde também perante o fiador por todas as perdas $\mathrm{e}$ danos que este pagar, e pelos que sofrer em razão da fiança.

Art. 833. O fiador tem direito aos juros do desembolso pela taxa estipulada na obrigação principal, e, não havendo taxa convencionada, aos juros legais da mora.

Art. 834. Quando o credor, sem justa causa, demorar a execução iniciada contra o devedor, poderá o fiador promover-lhe o andamento.

Art. 835. O fiador poderá exonerar-se da fiança que tiver assinado sem limitação de tempo, sempre que the convier, ficando obrigado por todos os efeitos da fiança, durante sessenta dias após a notificação do credor.

Art. 836. A obrigação do fiador passa aos herdeiros; mas a responsabilidade da fiança se limita ao tempo decorrido até a morte do fiador, e não pode ultrapassar as forças da herança. Seção III

\section{Da Extinção da Fiança}

Art. 837. O fiador pode opor ao credor as exceções que lhe forem pessoais, e as extintivas da obrigação que competem ao devedor principal, se não provierem simplesmente de incapacidade pessoal, salvo o caso do mútuo feito a pessoa menor.
Art. 838. O fiador, ainda que solidário, ficará desobrigado:

I - se, sem consentimento seu, o credor conceder moratória ao devedor; II - se, por fato do credor, for impossível a sub-rogação nos seus direitos e preferências;

III - se o credor, em pagamento da dívida, aceitar amigavelmente do devedor objeto diverso do que este era obrigado a the dar, ainda que depois venha a perdê-lo por evicção.

Art. 839. Se for invocado o benefício da excussão e o devedor, retardandose a execução, cair em insolvência, ficará exonerado o fiador que o invocou, se provar que os bens por ele indicados eram, ao tempo da penhora, suficientes para a solução da dívida afiançada."

"PARTE GERAL.. LIVRO III, DOS FATOS JURÍDICOS, TÍTULO I, DO NEGÓCIO JURÍDICO, CAPÍTULO I

Disposições Gerais

Art. 104. A validade do negócio jurídico requer:

I - agente capaz;

II - objeto lícito, possível, determinado ou determinável;

III - forma prescrita ou não defesa em lei. Art. 107. A validade da declaração de vontade não dependerá de forma especial, senão quando a lei expressamente a exigir.

Art. 108. Não dispondo a lei em contrário, a escritura pública é essencial à validade dos negócios jurídicos que visem à constituição, transferência, modificação ou renúncia de direitos reais sobre imóveis de valor superior a trinta vezes o maior salário mínimo vigente no País.

Art. 109. No negócio jurídico celebrado com a cláusula de não valer sem 
instrumento público, este é da substância do ato.

Art. 110. A manifestação de vontade subsiste ainda que o seu autor haja feito a reserva mental de não querer o que manifestou, salvo se dela o destinatário tinha conhecimento.

Art. 113. Os negócios jurídicos devem ser interpretados conforme a boa-fé e os usos do lugar de sua celebração.

Art. 114. Os negócios jurídicos benéficos e a renúncia interpretam-se estritamente.

\section{CAPÍTULOV}

Da Invalidade do Negócio Jurídico

Art. 166. É nulo o negócio jurídico quando:

I - celebrado por pessoa absolutamente incapaz;

II - for ilícito, impossível ou indeterminável o seu objeto;

III - o motivo determinante, comum a ambas as partes, for ilícito;

IV - não revestir a forma prescrita em lei;

$\mathrm{V}$ - for preterida alguma solenidade que

a lei considere essencial para a sua validade;

VI - tiver por objetivo fraudar lei imperativa;

VII - a lei taxativamente o declarar nulo, ou proibir-lhe a prática, sem cominar sanção. Art. 167. É nulo o negócio jurídico simulado, mas subsistirá o que se dissimulou, se válido for na substância e na forma.

$\S 1^{\circ}$ Haverá simulação nos negócios jurídicos quando:

I - aparentarem conferir ou transmitir direitos a pessoas diversas daquelas às quais realmente se conferem, ou transmitem;

II - contiverem declaração, confissão, condição ou cláusula não verdadeira; III - os instrumentos particulares forem antedatados, ou pós-datados.
$\S 2^{\circ}$ Ressalvam-se os direitos de terceiros de boa-fé em face dos contraentes do negócio jurídico simulado.

Art. 168. As nulidades dos artigos antecedentes podem ser alegadas por qualquer interessado, ou pelo Ministério Público, quando lhe couber intervir.

Parágrafo único. As nulidades devem ser pronunciadas pelo juiz, quando conhecer do negócio jurídico ou dos seus efeitos e as encontrar provadas, não lhe sendo permitido supri-las, ainda que a requerimento das partes.

Art. 169. O negócio jurídico nulo não é suscetível de confirmação, nem convalesce pelo decurso do tempo.

Art. 170. Se, porém, o negócio jurídico nulo contiver os requisitos de outro, subsistirá este quando o fim a que visavam as partes permitir supor que o teriam querido, se houvessem previsto a nulidade.

Art. 171. Além dos casos expressamente declarados na lei, é anulável o negócio jurídico:

I - por incapacidade relativa do agente; II - por vício resultante de erro, dolo, coação, estado de perigo, lesão ou fraude contra credores.

Art. 172. O negócio anulável pode ser confirmado pelas partes, salvo direito de terceiro.

Art. 173. O ato de confirmação deve conter a substância do negócio celebrado e a vontade expressa de mantê-lo.

Art. 174. É escusada a confirmação expressa, quando o negócio já foi cumprido em parte pelo devedor, ciente do vício que o inquinava.

Art. 175. A confirmação expressa, ou a execução voluntária de negócio anulável, nos termos dos arts. 172 a 174, 
importa a extinção de todas as ações, ou exceções, de que contra ele dispusesse o devedor.

Art. 176. Quando a anulabilidade do ato resultar da falta de autorização de terceiro, será validado se este a der posteriormente.

Art. 177. A anulabilidade não tem efeito antes de julgada por sentença, nem se pronuncia de ofício; só os interessados a podem alegar, e aproveita exclusivamente aos que a alegarem, salvo o caso de solidariedade ou indivisibilidade.

Art. 178. É de quatro anos o prazo de decadência para pleitear-se a anulação do negócio jurídico, contado:

I - no caso de coação, do dia em que ela cessar;

II - no de erro, dolo, fraude contra credores, estado de perigo ou lesão, do dia em que se realizou o negócio jurídico; III - no de atos de incapazes, do dia em que cessar a incapacidade.

Art. 179. Quando a lei dispuser que determinado ato é anulável, sem estabelecer prazo para pleitear-se a anulação, será este de dois anos, a contar da data da conclusão do ato.

Art. 180. O menor, entre dezesseis e dezoito anos, não pode, para eximir-se de uma obrigação, invocar a sua idade se dolosamente a ocultou quando inquirido pela outra parte, ou se, no ato de obrigar-se, declarou-se maior.

Art. 181. Ninguém pode reclamar o que, por uma obrigação anulada, pagou a um incapaz, se não provar que reverteu em proveito dele a importância paga.

Art. 182. Anulado o negócio jurídico, restituir-se-ão as partes ao estado em que antes dele se achavam, e, não sendo possível restituí-las, serão indenizadas com o equivalente.

Art. 183. A invalidade do instrumento não induz a do negócio jurídico sempre que este puder provar-se por outro meio.

Art. 184. Respeitada a intenção das partes, a invalidade parcial de um negócio jurídico não o prejudicará na parte válida, se esta for separável; a invalidade da obrigação principal implica a das obrigações acessórias, mas a destas não induz a da obrigação principal.."

\section{JURISPRUDÊNCIA}

$\mathrm{Na}$ legislação encontram-se genericamente reguladas as situações da vida, mas longe de resolvê-las em sua totalidade, apenas apontam caminho que nem sempre se encaixa no fato sob ótica ou é seguido por aqueles a quem dirigidas as suas respectivas incidências.

Nesse passo, necessário e de todo recomendável que se tenha como fonte não apenas as leis comuns ou esparsas, mas também a jurisprudência que analisa reiterados casos concretos e melhor define a correta e adequada aplicação do dispositivo legal sob ótica.

Nesse teor, como fonte criativa que se torna na lacuna da lei, na controvérsia ou mesmo na mera pretensão resistida, apresenta a jurisprudência variada gama de ocorrências a serem analisadas e, ainda que assim seja, na exata medida que alcança o estrito segmento contido neste trabalho, Fiança sem Outorga Uxória: Causa de Nulidade, Anulabilidade ou Ineficácia?, e na conformidade do que se pode constatar e dimensionar com as ementas abaixo colacionadas:

“LOCAÇÃO. AÇÃO DE DESPEJO POR FALTA DE PAGAMENTO C/C 
AÇÃO DE COBRANÇA. Contrato de locação prorrogado por prazo indeterminado. Fiança. Exoneração. Caso concreto. Matéria de fato. Exegese de cláusula contratual. $\mathrm{Na}$ espécie, uma vez prorrogada a locação por tempo indeterminado, a fiança não se resolve por si mesma, devendo os fiadores agir conforme o disposto no art. 1.500 do Código Civil; não o fazendo, serão responsáveis pelo pagamento dos alugueis ate a desocupação do imóvel e a entrega das chaves. Apelo provido, sentença desconstituída. (Apelação Cível no 70004278131, Décima Quinta Câmara Cível, Tribunal de Justiça do RS, relator: Des. Vicente Barrôco de Vasconcellos, julgado em 19/06/02).

\section{AÇÃO ORDINÁRIA DE COBRANÇA.} Juros remuneratórios. Não-limitação. Dependendo o par. $3^{\circ}$ do art. 192 da CF de regulamentação, conforme interpretação do Pretório Excelso, legal a pactuação da taxa de juros remuneratórios acima do limite de $12 \%$ ao ano. Às instituições financeiras não se aplica, no particular, o disposto no Decreto n. ${ }^{\circ} 22.626 / 33$. Fiança. Falta de outorga uxória. Anulabilidade do ato. A falta de outorga uxória à prestação de fiança constitui ato anulável, porque somente à mulher e seus herdeiros compete invalidá-la. Exegese do art. 239 do CC. Apelação provida. TRIBUNAL TARGS, RECURSO APC N. ${ }^{\circ} 197210107,13 / 08 / 98$, Décima Oitava Câmara Cível, Rel. Wilson Carlos Rodycz, ORIGEM: Estrela. REFLEG. CF-192, par-3 de 1988.
ASSUNTO: 1. - Falta de efetividade. Ineficácia. Taxa acima limite. Instituição financeira. 2. - Nulidade.

EMBARGOS À EXECUÇÃO. FIANÇA SEM OUTORGA UXÓRIA. ANULABILIDADE. A fiança prestada pelo marido sem o consentimento da mulher é ato anulável, estando legitimados para propor a anulatória somente o cônjuge ou seus herdeiros (art. 239 do Código Civil). Apelo improvido. REFLEG. CC-239; ASSUNTO: 1. Fiança. Falta de Outorga Uxória. Nulidade. Legitimação Ativa. Mulher ou Herdeiros. 2. Embargos do devedor. DECISÃO: Negado provimento. Unânime. TRIBUNAL TARGS, RECURSO APC N. ${ }^{\circ} 196245641,20 /$ 03/97, Segunda Câmara Cível, Rel. Roberto Laux, ORIGEM: Carazinho.

EMBARGOS Á EXECUÇÃO. FIANÇA. AUSÊNCIA DE OUTORGA UXÓRIA. ANULABILIDADE. INAPLICABILIDADE DO PARÁGRAFO ÚNICO DO ART. 298 DO CPC. APELAÇÃO NÃO PROVIDA. TRIBUNAL TARGS, RECURSO APC No 196135420, 11/12/96, Sétima Câmara Cível, DECISÃO: Negado provimento. Unânime. Rel. Roberto Expedito da Cunha Madrid, Três de Maio REFLEG. CPC-298; JURISPR. RP v-6 p-317; ASSUNTO: 1. Fiança. Falta de outorga uxória. Anulabilidade. 2. Execução. Co-devedor. Falta de citação. Embargos do devedor. Nulidade. Inocorrência. TIPO CÍVEL. 
NOTA DE CRÉDITO COMERCIAL. EMBARGOS. FIANÇA. OUTORGA UXÓRIA. ATO ANULÁVEL. JUROS REMUNERATÓRIOS. A fiança prestada pelo marido sem consentimento da mulher é ato anulável, estando legitimada apenas a mulher ou seus herdeiros. Questão superada, entretanto, pelo afastamento da fiança, ante $\mathrm{o}$ assentimento tácito do exeqüente. Os juros remuneratórios devem paramentar-se em $1 \%$ ao mês, sem socorro a argumentos constitucionais, pois em período de estabilidade monetária, esta é tradição nacional, à vista de vários diplomas. Apelação provida, em parte. ASSUNTO: 1. Nota de crédito comercial. Execução. Embargos do devedor. 2. Fiança. Falta de outorga uxória. - Anulabilidade. Nulidade. Legitimação ativa. Mulher ou herdeiros. 3. Juros reais. Interpretação. Percentual. Limite. DECISÃO: Dado provimento parcial. Unânime. TRIBUNAL TARGS, RECURSO APC N. ${ }^{\circ} 196146997,24 / 10 / 96$, Sexta Câmara Cível, RELATOR José Carlos Teixeira Giorgis, ORIGEM: Espumoso.

FIANÇA. AUSÊNCIA DE OUTORGA UXÓRIA. PROPOSTA A AÇÃO DE DESCONSTITUIÇÃO DA OBRIGAÇÃO PELA MULHER, QUE NÃO A FIRMOU, A PROCEDÊNCIA É IMPOSIÇÃO LEGAL, POUCO IMPORTANDO A DETERMINAÇÃO EM TORNO DA NULIDADE OU ANULABILIDADE DA FIANÇA. EXIGÊNCIA DE OUTORGA UXÓRIA QUE NÃO SE
VÊ ALTERAR PELA NOVA CONSTITUIÇÃO FEDERAL. IRRELEVÂNCIA, OUTROSSIM, DE O FIADOR HAVER SE COMPROMETIDO COMO PRINCIPAL PAGADOR E DEVEDOR SOLIDÁRIO, DESDE QUE, MESMO ASSIM, MANTIDA A NATUREZA DA FIANÇA COMO TAL. HONORÁRIOS FIXADOS COM MODERAÇÃO. APELAÇÃO IMPROVIDA. TRIBUNAL TARGS, RECURSO APC N. ${ }^{\circ} 195059332,22 / 06 / 95$, SEXTA CÂMARA CÍVEL, RELATOR MARCELO BANDEIRA PEREIRA, ORIGEM: PORTO ALEGRE. REFLEG. CC-235 INC-III; CC-242 INC- ASSUNTO: 1. FIANÇA. FALTA DE OUTORGA UXÓRIA. NULIDADE. - ANULABILIDADE. 2. HONORÁRIOS ADVOCATÍCIOS. FIXAÇÃO NA SENTENÇA. DECISÃO: NEGADO PROVIMENTO. UNÂNIME. TIPO CÍVEL.

FIANÇA. A AUSÊNCIA DE OUTORGA UXÓRIA NÃO NULIFICA A FIANÇA. APENAS IMPLICA EM INEFICÁCIA RELATIVA DA MESMA EM FACE DA ESPOSA. INEFICÁCIA ESTA, DE RESTO, A SER ALEGADA, PRIVATIVAMENTE, PELO CÔNJUGE. CASO EM QUE, DE RESTO, O EMBARGANTE ASSUMIU DÍVIDA TAMBÉM COMO DEVEDOR SOLIDÁRIO. REFLEG. CC-263 INC$\mathrm{X}$; CC-239; CC-235; CC-178 PAR-9 AL-B. ASSUNTO: 1. FIANÇA. FALTA DE OUTORGA UXÓRIA. 
ANULABILIDADE. - VALIDADE. RESPONSABILIDADE. BEM PARTICULAR OU MEAÇÃO. - NULIDADE. LEGITIMAÇÃO ATIVA. MULHER OU HERDEIROS. 2. FIANÇA. EXECUÇÃO. DEVEDOR SOLIDÁRIO. DECISÃO: DADO PROVIMENTO. UNÂNIME. TRIBUNAL TARGS, RECURSO APC N. ${ }^{\circ}$ 195087622, 08/08/95, SEXTA CÂMARA CÍVEL, RELATOR ARMÍNIO JOSÉ ABREU LIMA DA ROSA. ORIGEM: FLORES DA CUNHA.

FIANÇA. ANULABILIDADE. É ANULÁVEL E NÃO NULA, A FIANÇA DESPROVIDA DE OUTORGA UXÓRIA (CC, ARTS. $145, \mathrm{~V}, 146,152$ E 239) COMPETINDO À MULHER LEGITIMIDADE PARA DEMANDAR A INVALIDAÇÃO (CC, ART. 239). REFLEG. CC-235 INC-III; CC-239; CC-145 INC-V; CC-152; CC-178 PAR9 INC-I LET-B; CC-146 PARÚNICO. JURISPR. APC 12651 TJRGS; APC 191108661 TARGS; JULGADOS TARGS V-12 P-166; V81 P-171; RJTJRGS V-42 P-58; RTJ V-36 P-559; V-54 P-138; V-55 P-384; V-56 P-743; V-61 P-676 RJTJRS, JULGADOS TARGS V-88 P-354 ACIGUAL APC 194143152 ARNO WERLANG ASSUNTO: FIANÇA. FALTA DE OUTORGA UXÓRIA. ANULABILIDADE. - NULIDADE. LEGITIMAÇÃO ATIVA. MULHER. DECISÃO: DADO PROVIMENTO. UNÂNIME. TRIBUNAL TARGS, RECURSO APC N. ${ }^{\circ} 193190071,30 /$
11/93, PRIMEIRA CÂMARA CÍVEL, RELATOR HEITOR ASSIS REMONTI, ORIGEM: PELOTAS. BIBLIOGR. - SANTOS, CAVALHO. "CÓdIGO CIVIL BRASILEIRO INTERPRETADO”. III, P-250, FREITAS BASTOS; - LEAL, A.L. CÂMARA. "DA PRESCRIÇÃO E DA DECADÊNCIA". P-381, 159. JULGADOS TARGS V-88 P-354, TIPO CÍVEL.

EXECUTIVO FISCAL. EMBARGOS. FIANÇA. NULIDADE DA FIANÇA PELO ANALFABETISMO DA FIADORA, RECONHECIDA DE OFÍCIO, E ANULABILIDADE POR FALTA DE OUTORGA MARITAL, QUE DEPENDE DE SUSCITAÇÃO DO CÔNJUGE PRETERIDO. A PENHORA EM BENS IMÓVEIS DOS FIADORES, NÃO VINCULA PROCESSUALMENTE A FIADORA NÃO ATADA, NEM INTIMADA DA CONSTRIÇÃO. PROSSEGUIMENTO DA EXECUÇÃO. TRIBUNAL TJRGS, RECURSO APC N. ${ }^{\circ}$ 592136022, 18/ 02/93, SEGUNDA CÍVEL, RELATOR SERGIO JOSÉ DULAC MULLER, ORIGEM: TAQUARI. (RESUMO) REFLEG. CC-43 INC-I LF-6830 DE 1980 ART-12 PAR-2 CTN-109 ASSUNTO: 1. PROCESSO CIVIL. 2. ICMS. COBRANÇA. 3. EXECUTIVO FISCAL. - FIANÇA. FIADOR ANALFABETO. EFEITOS QUANTO À GARANTIA PRESTADA. - PENHORA. INTIMAÇÃO. EFEITOS. CITAÇÃo do DEVEdor. CITAÇÃO DO FIADOR. FALTA. 
EFEITOS. 4. FIADOR. DÉBITOS FISCAIS. 5. EMBARGOS DO DEVEDOR. - PENHORA EM EXECUTIVO FISCAL. - AVALIAÇÃO DOS BENS PENHORADOS. - BENS IMÓVEIS DO FIADOR. INTIMAÇÃO DO CÔNJUGE. FALTA. EXECUTIVO FISCAL. - FIANÇA. ANULABILIDADE. ILEGITIMIDADE DO DEVEDOR PARA SUSCITAR. - CRÉDITO FISCAL E MULTA. 6. FIANÇA. - OUTORGA UXÓRIA. FALTA. EFEITOS. NULIDADE. CONHECIMENTO DE OFÍCIO. EFEITOS. - ANULABILIDADE. FONTE: JURISPRUDÊNCIA TJRS, C-CÍVEIS, 1993, V1, T-9, P-287-290, TIPO CÍVEL.

FIANÇA - OUTORGA UXÓRIA - AUSÊNCIA - NULIDADE DA GARANTIA - APLICAÇÃO DO ART. 242, I, C/C O ART. 235, III, DO CC - INTERPRETAÇÃO DO ITEM I DO ART. $5^{\circ}, \mathrm{C} / \mathrm{C} \mathrm{O} \S 5^{\circ}$ DO ART. 226, AMBOS DA CF - EXEGESE DA IGUALDADE ENTRE HOMEM E MULHER - A nulidade da fiança por ausência de outorga é absoluta e não convalesce, conforme demonstra o disposto nos arts. 235, III, e 242, I, do CC, descabendo incluir-se meação de pessoa que sequer foi parte do contrato de fiança e que, por isso, dispensada do ônus de provar. ( $2^{\circ}$ TACSP - Ap. c/rev. 306.986-0-00 - $6^{\text {a }}$ - Rel. Juiz Lagrasta Neto - J. 05.02.92) (JTACSP 135/357).

EMBARGOS DO DEVEDOR. LOCAÇÃO. FIANÇA. É ANULÁVEL,
E NÃO NULA, A FIANÇA DESPROVIDA DE OUTORGA UXÓRIA, COMPETINDO À MULHER LEGITIMIDADE PARA DEMANDAR A INVALIDAÇÃO. HIPÓTESE EM QUE, DEMANDADO O DESFAZIMENTO DO ATO, A RESPECTIVA SENTENÇA, EM SEU DISPOSITIVO LIMITOU-SE A EXCLUIR A MULHER DA RELAÇÃO PROCESSUAL EXECUTÓRIA. SUBSISTÊNCIA DA OBRIGAÇÃO EM RELAÇÃO AO MARIDO. EXCLUSÃO, TODAVIA, DAS DESPESAS DE RECUPERAÇÃO DO IMÓVEL, PORQUE IMPROVADAS NÃO DECORRESSEM DE USO NORMAL, E DA SUCUMBÊNCIA NA AÇÃO DE DESPEJO, POR FALTA DE INTIMAÇÃO DO FIADOR. APELAÇÃO PROVIDA EM PARTE. TRIBUNAL TARGS, RECURSO APC N. ${ }^{\circ} 191108661,25 /$ 09/91, TERCEIRA CÂMARA CÍVEL RELATOR ARAKEN DE ASSIS, ORIGEM: PELOTAS. REFLEG. LILF-6649 DE 1979 ART-22; CC-145 INC-V; CC-146 PAR-ÚNICO; CC152; 02/08/99 15:06:27, TJRS Jurisprudência Cível Unificada, Página: 2 CC-239; CC-245 INC-III; CC-1486; CPC-471 INC-II RJTJRS, JULGADOS TARGS V-81 P-171 ASSUNTO: 1. FIANÇA. FALTA DE OUTORGA UXÓRIA.

ANULABILIDADE. - NULIDADE. LEGITIMAÇÃO ATIVA. MULHER. 2. LOCAÇÃO. EXECUÇÃO. FIANÇA. FALTA DE INTIMAÇÃO AÇÃO DE DESPEJO. EFEITOS. - 
COBRANÇA ALUGUEL, CUSTAS E HONORÁRIOS ADVOCATÍCIOS. REPARAÇÃO DE DANO. FALTA DE PROVA. EXCLUSÃO. DECISÃO: DADO PROVIMENTO. UNÂNIME. BIBLIOGR. DALL'AGNOL JR. ANTONIO JANYR. INVALIDADES PROCESSUAIS, PORTO ALEGRE, LEJUR, 1989, N-3.1, P-31 JULGADOS TARGS V-81 P-171. TIPO CÍVEL."

\section{ANÁLISE RELACIONAL E CONFRONTO DOS INSTITUTOS}

Ao teor do quanto exposto até aqui, e consoante o que dispõe a legislação, ao que prega a doutrina e ao que comprova a própria jurisprudência, e segundo a ótica deste articulista, o Contrato de Fiança sem Outorga Uxória não é causa de Nulidade, não é causa de Anulabilidade e não é causa de Ineficácia. E tal importa dizer por quê não é e/ou justificar o que seja.

Não se trata de nulidade porque a nulidade somente pode alcançar a quem não participou do ato de concessão da fiança com a sua anuência, com o seu assentimento, com o seu livre consentimento.

Não se trata de anulabilidade porque não se pode anular o ato que foi regularmente praticado por agente capaz, objeto lícito e não vedado em lei, sem outra causa de anulabilidade senão essa ora em estudo. Por força disso, a validade do ato não pode ser anulada.

Não se trata de ineficácia porque somente os atos que padecem de vícios insanáveis é que poderão ser tidos por ineficazes.
Mas um vício parcial existe a macular esse contrato de fiança sem outorga uxória: a ausência da manifestação de vontade daquele que estava obrigado a participar com o seu consentimento ao ato de concessão da fiança.

Desse modo, marido ou mulher, um ou outro não está obrigado a responder pelos efeitos que possam vir a ser causados em sua esfera jurídica obrigacional na medida em que a isso não deram causa.

Nesse ponto, não pode ela ou ele, conforme se der o caso, serem alcançados pelos efeitos da fiança, aquele que não contratou e que não pode responder pelos seus efeitos. E nesse caso, trata-se, portanto, de ineficácia parcial, ou ineficácia relativa, mas nunca nulidade, anulabilidade, ou ineficácia, pura e simplesmente.

O mesmo raciocínio, no entanto, serve igualmente, data venia, para os que entendem que se trata de nulidade, de anulabilidade ou ineficácia.

Em qualquer dos casos, não se nulificará o ato, não se anulará o ato, não se ditará a ineficácia do ato, senão em relação à meação daquele de quem ausente o consentimento para a concessão da garantia, pois o outro cônjuge o praticou segundo sua perfeita e plena vontade, não podendo, pois, cogitar-se de nulidade, anulabilidade, ou ineficácia, senão parcial, relativamente ao cônjuge que não participou do ato, negócio jurídico acessório, o contrato de concessão da fiança.

Até porque, e isso subjaz ao entendimento aqui esposado, jamais se 
cogitará de nulidade, de anulabilidade, ou de ineficácia, senão naquelas oportunidades em que o concedente da fiança sem outorga uxória impossibilitase de cumprir a obrigação do afiançado e, por causa disso, é judicialmente acionado a responder com os bens que possui, no caso, em comunhão com aquela ou aquele que deveria ter participado do ato com a sua anuência.

E se não produziu a concessão de garantia, sua meação nesses bens levados à constrição, estarão, necessariamente, parece-me, preservados pelo juízo que da causa tomar conhecimento.

E a meu pensar, ver e sentir, isso ocorre porque nem a lei, nem a doutrina, podem superar o fato consumado que deriva da circunstância de o concedente da fiança sem outorga uxória ou marital espontaneamente satisfazer perante o credor a obrigação não cumprida pelo afiançado devedor, seja fazendo-o em nome próprio ou, e não raro, em nome do próprio devedor.

E nesse passo, não há de cogitar-se de nulidade, de anulabilidade ou de ineficácia, pois, ao contrário, o contrato de fiança sem outorga uxória ou marital teve plena e absoluta existência, plena e absoluta validade e plena e absoluta eficácia.

E tal se explica porque a procura e a pesquisa na identificação do que seja uma coisa ou outra tem vertente na confusão, similitude ou sinonímia verificada tanto na legislação quanto na doutrina e mesmo na jurisprudência, quanto ao uso da nomenclatura relativa à nulidade, anulabilidade e ineficácia, aplicando indistintamente uma ou outra, mas sempre na mesma direção, no mesmo sentido: o resultado.

No entanto, importante frisar, o meio através do qual a isso se chegou, como visto, não tem maior relevância segundo a ótica deste articulista, na razão direta de que a única coisa que tem significado teleológico e finalístico ocorre exatamente no campo, no âmbito, do resultado, dos efeitos, da eficácia ou não que possa ter a fiança concedida sem outorga do outro cônjuge.

Por outro lado, a meu ver e sentir, conquanto respeite e acolha as idéias e ensinamentos dos mestres, considero que não importa o rótulo que se dê aos problemas criados pelos fatos no efervescer do mundo social, pois em regime democrático e estado de direito o que importa, no fundo, é a solução equânime para o caso sub oculis. Por isso mesmo, de um contrato de fiança sem outorga uxória podem ser extraídas várias conclusões.

A primeira, é que pode mesmo tratar-se de nulidade. E se assim for, somente poderá tratar-se de nulidade mitigada, pois do cônjuge que concedeu a fiança sem qualquer outra causa de nulidade senão essa, não poderá pensarse em nulidade.

E ter-se-á obrigatoriamente de tratá-la de Nulidade Parcial Absoluta, onde a nulidade atinge tão-somente a pessoa do cônjuge que não deu o consentimento. Por certo que tal implica em processo, de regra executivo, e já na fase de constrição de bens que pertencem a ambos os cônjuges, um deles surpreendido na medida em que nenhum gravame criou para os seus 
bens, relativamente a essa fiança, na medida em que não a concedeu.

Veja-se, entrementes, que essa declaração judicial de nulidade parcial absoluta não terá qualquer significado e para nada servirá, objetivamente, se não tiver aplicação no plano da eficácia, ou seja, ela corresponderá ao juiz da causa afirmar que a fiança não tem eficácia em relação ao cônjuge não-participante da fiança, pois se o cônjuge que não concedeu a fiança não viesse a ser afetado pela constrição, não haveria nulidade conhecida e, portanto, não reconhecida como tal em juízo, e, por isso mesmo, sem aplicação no campo que realmente significa resultados: os efeitos da fiança, a eficácia da fiança.

A segunda conclusão é que pode também tratar-se de anulabilidade, mas Anulabilidade Parcial, pois não se poderá anular o ato existente, válido e eficaz, relativamente ao cônjuge que concedeu a fiança sem qualquer outra causa de anulabilidade senão essa decorrente da falta de outorga, uxória ou marital.

Nesse passo, então, necessário apontar a diferença entre a nulidade parcial absoluta e a anulabilidade parcial que residem sempre, ambas, na evitação ou impedimento de atuação plena dos efeitos da fiança, do campo da eficácia, na esfera jurídica obrigacional daquele cônjuge que não concedeu a fiança.
A nulidade parcial absoluta decorre da operatividade da defesa já na esfera de constrição dos bens do cônjuge não participante da fiança, enquanto que a anulabilidade parcial pode ser argüida por quem a aproveita (o outro cônjuge) a partir do momento em que tiver ciência da concessão de certa fiança sem outorga uxória, ainda que, a esse tempo, não exista inadimplemento do devedor ou constrição de bens.

Contextualizando, a busca do reconhecimento judicial da declaração de anulabilidade parcial vai obter o mesmo efeito da declaração de nulidade parcial absoluta, esta já no âmbito processual executivo, enquanto que aquela, necessariamente, ainda no campo do processo de conhecimento.

A terceira e definitiva conclusão é que uma circunstância ou outra se constituem em meras facetas dos fatos que levam à concessão da fiança sem outorga uxória ou marital, que na sua elaboração, na sua efetuação, não cogitam do enquadramento legal, doutrinário ou jurisprudencial, mas cujo interesse e alcance tem por objetivo único a ineficácia da fiança, relativamente ao cônjuge preterido. E, como visto, Ineficácia Parcial.

Em outras palavras, a argüição de nulidade parcial absoluta ou anulabilidade parcial seriam apenas o modus faciendi, ${ }^{37}$ segundo Humberto

37 Gilberto Caldas, In O Latim no Direito. São Paulo, Brasiliense Coleções, 1986, p.188: MODUS FACIENDI. Maneira de fazer. Citando Humberto Theodoro Júnior: "É o procedimento, de tal sorte, que dá exterioridade ao processo, revelando-se o modus faciendi com que se vai atingir o escopo da tutela jurisdicional." (Processo Cautelar, Humberto Theodoro Júnior, 1. ed., p.26). 
Theodoro Junior, citado por Gilberto Caldas, de atingir o objetivo único, que é a ineficácia, que pode ser argüida diretamente pelo cônjuge não concedente da fiança, como Ineficácia Parcial, no processo executivo, durante ou antes da fase de constrição, ou ainda em processo típico de conhecimento, quando o objetivo já não seria evitar a imediata constrição de seus bens, resguardando-lhe a meação, mas prevenir a meação que pode a vir a ser atingida no futuro, caso o afiançado devedor venha a não cumprir a obrigação assumida perante o credor, garantida pelo outro cônjuge.

\section{EFEITOS EX TUNC E EX NUNC}

Nessa contextualização, não há que se confundir o poder potestativo processual típico da nulidade com a faculdade processual exsurgente da anulabilidade, poderes traduzidos em operatividade distinta de direitos, mas que convergem para um único e exclusivo fim: o efeito de direito material que resulta em declaração judicial negativa da obrigação na esfera obrigacional do cônjuge que não concedeu a fiança, e na medida direta em que não se obrigou e, por isso mesmo, não pode vir a sofrer qualquer constrição em seus bens.

$\mathrm{Ou}$, em outras palavras, materialmente o contrato de fiança não lhe é oponível porquanto não-eficaz, visto que essa eficácia nasce (e só daí pode nascer) da obrigação constituída segundo o consentimento daquele que se obriga ou está legalmente obrigado (e este não é caso em apreço).
E isso, a meu pensar e sentir, é ineficácia parcial, pois diretamente relacionada entre o contrato acessório e o não-concedente da fiança, ainda que permaneça o contrato com eficácia plena em relação ao cônjuge autor da garantia, pela qual responderá até o limite de sua meação nos bens constritos ou a constritar.

Nesse passo, rogata maxima venia, os efeitos da declaração judicial haverão de ser sempre ex tunc, desde o momento em que concedida a fiança pelo outro cônjuge, sem outorga uxória, desimportando que ela se faça mediante a potestatividade da nulidade ou da faculdade da anulabilidade, no processo de conhecimento.

Por conseqüência, venia concessa, logo se conclui que os efeitos ex nunc, desde o momento em que exarada a declaração, não tem aplicação à fiança sem outorga uxória porque não se pode aplicar esse princípio da faculdade processual quando do que se cogita é da estrutura de direito material (segundo o qual ninguém se obriga sem ciência - em não se tratando - como não se trata, de obrigação ditada pela lei, que ninguém pode ignorar), ao qual se subsume a anulabilidade dentro da principiologia adotada pelo Código Civil Brasileiro, onde direito menor não prevalece ou se sobrepõe sobre direito maior (a não-obrigação), e ainda que nele mesmo prevista, porque disposição de menor hierarquia, a anulabilidade.

Oportuno lembrar que afora os casos de silêncios jurídicos, os denominados silêncios eloqüentes, que 
significa ciência sobre o que deve a parte silenciar ou manifestar-se (do que não se cogita ou não tem aqui aplicação), não há no Código Civil Brasileiro, obrigação que decorra da não-obrigação ou da nãociência de uma obrigação qualquer.

Por isso, data venia, relevante ainda salientar que a questão em exame se resolve mesmo, materialmente falando, ou se exaure a finalidade da concreção do fato, não no plano da existência (pois fiança não existe para o cônjuge que não a concedeu) e pode levar à nulidade parcial absoluta, e tampouco no plano da validade, o que levaria a anulabilidade, posto que não pode valer o que não existe, o que levaria à anulabilidade parcial, e ainda que tal venha a se definir num processo, o plano que realmente faz resultados é o plano da eficácia material, do qual nem a nulidade, nem a anulabilidade podem escapulir.

E isso ainda que o plano da eficácia material, para contestar ou defender o direito da não-obrigação perante a garantia da fiança concedida pelo outro cônjuge, somente se alcance mediante processo judicial, geralmente já na fase executiva, mas que também pode, como antes assinalado, ser exercido esse direito através do processo de conhecimento e sem que para tal, tenha a decisão judicial que reconhecer a ineficácia parcial da fiança somente a partir de então.

\section{CONCLUSÃo}

Em suma, o ato não-eficaz somente pode decorrer de ato não-existente ou não-válido, circunstâncias que coexistem, coabitam, no contrato de fiança sem outorga uxória ou marital, relativamente ao cônjuge que não concedeu a fiança.

Aliás, de todo oportuno lembrar que é pela interpretação que se conhece a concepção de vida do intérprete, até porque, e por isso mesmo, impregnada de subjetivismo, na cátedra de Eduardo Couture. ${ }^{38}$

Nesse passo, longe deste trabalho vir para contrariar tudo quando já dito até então, vem apenas para acrescentar que a causa jurídica eficiente na definição de o contrato de fiança sem outorga uxória ser causa de nulidade, de anulabilidade ou de ineficácia, é, como exposto, a Ineficácia Parcial, não a nulidade, que é causa jurídica de argüição plena, ou a anulabilidade, que é causa jurídica de argüição mitigada, relativa, ou parcial, pois são ambas necessariamente convergentes ao desvelamento, à revelação daquela, a causa jurídica eficiente.

Por isso, resulta concluir que o contrato de fiança sem outorga uxória (ou marital) é causa de Ineficácia Parcial, ou, subsidiariamente, ainda que direcionada para esse mesmo objetivo (no qual se subsume), a ineficácia, causa

38 "Interpretar é, ainda que inconscientemente, tomar partido por uma concepção de direito, o que significa dizer por uma concepção de vida. Interpretar é dar vida a uma norma. (...) O raciocínio e a intuição, todavia, pertencem ao homem, e, por isso, estão prenhes de subjetivismo. Todo intérprete é, embora não o queira, um filósofo e um político da Lei." Eduardo Couture. 
de nulidade parcial absoluta ou anulabilidade parcial, e seus efeitos exsurgentes desde o momento em que deveria ter existido a outorga uxória ou marital.

Por derradeiro, no âmbito do processo de conhecimento poderá ser também identificada como causa de
Nulidade Parcial Absoluta ou causa de Anulabilidade Parcial, embora no processo executivo, pela concreção da argüição de direito material, resulte sempre em Causa de Ineficácia Parcial, porquanto constitui o fim último, o resultado, da análise ora enfrentada.

\section{REFERÊNCIAS}

ADIERS, Moacir. Caracterização da Boa-Fé na Posse como uma Arte Jurisprudencial. Porto Alegre, Ajuris n.41, 1987.

AGUIAR JUNIOR, Ruy Rosado de. Interpretação. Porto Alegre, Ajuris n.45, 1989.

ASSIS, Araken de. Locação e Despejo. Porto Alegre, Sérgio Antônio Fabris Editor, 1991.

BARROS, Wellington Pacheco. A Interpretação dos Contratos. Porto Alegre, Ajuris n.49, 1990.

—_ A Interpretação Sociológica do Direito. Porto Alegre, Livraria do Advogado, 1995.

—. Dimensões do Direito. 2.ed. Porto Alegre, Livraria do Advogado, 1999.

—. Curso de Direito Agrário. 3.ed., Porto Alegre, Livraria do Advogado, 198. - Contrato de Arrendamento Rural. Porto Alegre, Livraria do Advogado, 1998.

BATALHA, Wilson de Souza Campos. Lei das Locações Prediais Urbanas: Comentários. São Paulo, LTR, 1992.

CALDAS, Gilberto. Nova Lei do Inquilinato Comentada. São Paulo, Ediprax, 1991.

—_. A Técnica do Direito, v.4, A Técnica da Locação de Imóveis

(Comercial e Residencial). São Paulo, Brasiliense Coleções, 1986. . O Latim no Direito. São Paulo, Brasiliense Coleções, 1986.

CARVALHO, Ivan Lira de. A interpretação da Norma Jurídica. Ajuris n.58, 1993.

CERVO, Amado Luiz e BERVIAN, Pedro Alcino. Metodologia Científica, 2.ed. rev. e ampl. São Paulo, McGraw-Hill do Brasil, 1978.

CIRNE LIMA, Ruy. Princípios de Direito Administrativo, 6.ed. São Paulo, Editora Revista dos Tribunais, 1987.

CRETELLA JUNIOR, José. Manual de Direito Administrativo, 6.ed. Rio de Janeiro, Editora Forense, 1992. - Curso de Direito Romano. O direito romano e o direito civil brasileiro, 7.ed. rev. e aum. Rio de Janeiro, Editora Forense, 1980.

DIAS, Nadir Silveira. Locação de Imóveis Comentada em Locuções e Verbetes. Porto Alegre, Livraria do Advogado, 1999.

DINIZ, Maria Helena. Lei de Locações de Imóveis Urbanos Comentada. São Paulo, Saraiva, 1992.

—.Curso de Direito Civil Brasileiro, $1^{\circ}$ vol. Teoria Geral do Direito Civil, 4.ed. São Paulo, Editora Saraiva, 1986. 
EDITORAABRIL S.A. Manual de Estilo Editora Abril. Rio de Janeiro, Editora Nova Fronteira, 1990.

FERREIRA, Aurélio Buarque de Holanda. Dicionário Aurélio Básico da Língua Portuguesa. Folha de São Paulo/ Editora Nova Fronteira, 1995.

GASPERI, Ulysses de. Elementos de Economia (Economia Política), 5.ed. Porto Alegre, Sulina, 1970.

HOUAISS, Antônio. Direção de, Pequeno Dicionário Enciclopédico Koogan Larousse, Rio de Janeiro, Ed. Larousse do Brasil, 1992.

KASPARY, Adalberto J. Habeas Verba, Português para Juristas, Porto Alegre, Livraria do Advogado, 1994.

-O verbo na Linguagem Jurídica Acepções e Regimes. 2.ed. rev. e ampl. Porto Alegre, Livraria do Advogado, 1994.

LINDEMBERG FILHO, Sylvio de Campos. Venda de Imóveis, um Ato de Negociação. 1.ed. Porto Alegre, Sagra, 1990.

MACHADO NETO, Antônio Luís. Sociologia Jurídica. 4.ed. São Paulo, Saraiva, 1979.

MAXIMILIANO, Carlos. Hermenêutica e Aplicação do Direito. 8.ed. São Paulo, Freitas Bastos, 1965.

MELLO NETO, João Alfredo. Manual Teórico e Prático do Condomínio. 1.ed., Rio de Janeiro, Aide Ed., 1989.

NEVES, Iêdo Batista. Vocabulário Prático de Tecnologia Jurídica e de
Brocardos Latinos. Rio de Janeiro, APM Editora, 1987.

PACHECO, José da Silva. Comentários à Nova Lei sobre as Locações dos Imóveis Urbanos e seus Procedimentos. São Paulo, Revista dos Tribunais, 1992.

PEREIRA, Caio Mário da Silva. Instituições de Direito Civil, vol. I, Introdução ao Direito Civil, Teoria Geral de Direito Civil, 9.ed. Rio de Janeiro, Forense, 1986.

RIZZARDO, Arnaldo. A Nova Lei do Inquilinato. Porto Alegre, Ajuris n.54, 1992.

RODIGUES, SILVIO. Direito Civil, dos Contratos e das Declarações Unilaterais da Vontade, Vol..3, Editora Saraiva, 22.ed., 1994.

ROQUE LAUSCHNER, S.J. Lógica Formal. 3.ed. , Porto Alegre, Livraria Sulina Editora, 1969.

SILVA, José Henrique de Freitas Valle e. Manual Prático do Inquilinato. Porto Alegre, Ed. Pró-Viver, 1991.

SOUZA, Rui Barbosa de. Correspondência, Moderno Manual de Linguagem e Comunicação, 4.ed. Porto Alegre, Editora Rígel.

SOUZA, Sylvio Capanema de. A Nova Lei do Inquilinato Comentada. Rio de Janeiro; Saraiva, 1993.

- Da Locação do Imóvel Urbano, Direito e Processo, 1.ed., $2^{\mathrm{a}}$ tiragem. Rio de Janeiro, 1999.

TEMER, Michel. Elementos de Direito Constitucional. 10.ed., São Paulo, Malheiros Editores, 1996. 
